Article

\title{
How Do Intensification Practices Affect Weed Management and Yield in Quinoa (Chenopodium quinoa Willd) Crop?
}

\author{
Ali reza Safahani Langeroodi ${ }^{1}\left[\right.$, , Roberto Mancinelli ${ }^{2}\left[\right.$ and Emanuele Radicetti ${ }^{3, *(1)}$ \\ 1 Department of Agronomy, Payame Noor University, 8415683111 Tehran, Iran; safahani.ali@gmail.com \\ 2 Department of Agricultural and Forestry Sciences (DAFNE), University of Tuscia, Via San Camillo de Lellis \\ snc, 01100 Viterbo, Italy; mancinel@unitus.it \\ 3 Dipartimento di Scienze Chimiche e Farmaceutiche, Università di Ferrara, Via Luigi Borsari 46, \\ 44121 Ferrara, Italy \\ * Correspondence: emanuele.radicetti@unife.it
}

Received: 8 July 2020; Accepted: 27 July 2020; Published: 29 July 2020

check for updates

\begin{abstract}
Quinoa cultivation is well-adapted to sustainable cropping systems, even if seed yield could be severely limited due to several constraints, such as weeds. Field trials were performed in Gorgan (Iran) to quantify the effects of agro-ecological service crops (rye, $\mathrm{CC}_{\mathrm{r}}$; winter vetch, $\mathrm{CC}_{\mathrm{w}}$; and no cover, $\mathrm{CC}_{0}$ ), tillage regimes (conventional tillage, $\mathrm{CT}$; and no-tillage, $\mathrm{ZT}$ ), and herbicide rates $\left(100 \%\right.$ rate, $\mathrm{H}^{100} ; 75 \%$ rate, $\mathrm{H}^{75}$; and without herbicide, $\left.\mathrm{H}^{0}\right)$. Weed characteristics and quinoa yield were measured. Quinoa seed yield was the highest in $\mathrm{CC}_{\mathrm{w}}-\mathrm{ZT}-\mathrm{H}^{100}$. Seed yield in $\mathrm{H}^{100}$ and $\mathrm{H}^{75}$ were higher compared with $\mathrm{H}^{0}$ (2.30 vs. $1.58 \mathrm{tha}^{-1}$, respectively). Under conventional tillage, $46 \%$ of weed seeds were observed in the $0-10 \mathrm{~cm}$ soil layer and $54 \%$ in $10-20 \mathrm{~cm}$ soil layers, respectively, while, under no-tillage, about $63 \%$ of weed seeds were located up to $10 \mathrm{~cm}$ of soil. Amaranthus retroflexus $\mathrm{L}$. was the most abundant species. The total weed density was the lowest in $\mathrm{CC}_{\mathrm{r}}-\mathrm{ZT}-\mathrm{H}^{100}$ and tended to

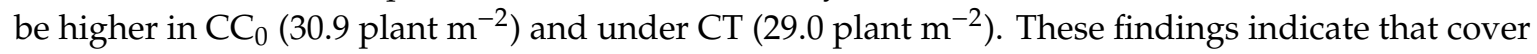
crops have potential for managing weeds in quinoa; however, their inclusion should be supported by chemical means to maintain high seed.
\end{abstract}

Keywords: conventional tillage; no-tillage; integrated weed management; rye; winter vetch

\section{Introduction}

Quinoa (Chenopodium quinoa Willd.) is an Amaranthaceae annual plant originated in the Andes region, where it was cultivated for several thousand years. Quinoa is grown for its tiny edible seeds and was used for human nutrition in the Andean mountains for a long time. In the last decades, interest in quinoa seeds for human nutrition has increased around the world. Indeed, from quinoa seeds one can obtain highly nutritious food products rich in proteins characterized by a wide range of amino acids, vital for supporting essential functions, and high values of micronutrients, such as vitamins and minerals. Furthermore, quinoa seeds contain antioxidants and fiber, while they are lacking in gluten. The nutritional profile of food products obtained from quinoa seeds allows for use in the same way as cereals and represents an ideal substitute for grains. All these characteristics have increased the interest in foods derived from quinoa seeds for human and animal feeding, and invite farmers to cultivate quinoa crop [1]. For this reason, the Food and Agriculture Organization of the United Nations (FAO) has recognized quinoa as a potential crop able to support growing food demand and food security in the future [2]. From an agronomical point of view, quinoa plants are characterized by a high adaptability to different environmental conditions that determine cultivation in different areas of the world and encourage interest from growers and food processing industry [3]. 
Information on the most suitable agronomical practices, especially weed management, are limited. In fact, weeds represent the main constraint in quinoa cultivation and its seed production could be substantially reduced if weeds are not properly managed, according to Jacobsen et al. [4]. Moreover, there are few registered active compounds suitable for chemical weed management and, at the moment, manual weed removal by hoe represents the practice most widely used for managing weeds in the crop. Next steps in quinoa research must be oriented to the evaluation of selective control strategies, such as herbicides, to be included as a part of an integrated weed management approach. This innovative approach should improve crop seed production by reducing the competitive ability of weeds, especially from those that are part of the same botanical family, such as Amaranthus retroflexus, which hinder selective weed management. However, to develop an effective weed management system a sustainable approach should be considered. Therefore, some agronomical practices, such as agro-ecological service crops and soil tillage, that generally have a great impact on weed establishment and growth $[5,6]$ must be evaluated in relation to quinoa cultivation. In fact, the combination of agro-ecological service crops and the arrangement of their residues could determine different levels of weed responses based on the qualitative and quantitative characteristics of the agro-ecological service crop residues and the type of soil tillage adopted [7]. The information obtained from such studies could support farmers in the decision process focused on a suitable approach to manage weeds in quinoa crops.

Although quinoa has been widely studied for its nutritional and healthy characteristics in human nutrition, knowledge on effects of integrated weed management strategies based on agro-ecological service crops, soil tillage and herbicide rate on weed characteristics in quinoa crops are missing. The study hypothesizes that the combination of agro-ecological service crops and soil tillage could support the decision-making of farmers to realize a sustainable strategy for weed management based on reduced herbicide rate that supports seed yield of quinoa crop. Therefore, the main aims of this study are: (i) To assess the suitability of ecological service crops cultivated before a quinoa crop, as a possibility to manage soil during the bare period, on weed characteristics in terms of biomass at their termination; (ii) to assess the changes in weed biomass and seed bank at quinoa harvest in response to different agro-ecological service crops, soil tillage adopted for agro-ecological service crop residue management, and herbicide rates; (iii) to determine whether different rates of herbicide could provide acceptable control of actual weeds in quinoa, and (iv) to evaluate whether quinoa plants were sufficiently tolerant to permit selective use of herbicide for weed control.

\section{Materials and Methods}

\subsection{Experimental Sites and Design}

Quinoa trials were conducted in the 2017 and 2018 growing seasons at the research farm of the College of Agriculture, Payame Noor University located in Gorgan, Iran (36 $50^{\prime} \mathrm{N} ; 54^{\circ} 22^{\prime} \mathrm{E}$, altitude: $61 \mathrm{~m}$ a.s.l.). The region has a typical semi-arid climate with long dry summer and cool winter. In both growing seasons, weather characteristics were recorded by a weather station located near the experimental fields. Averagely mean air temperatures during quinoa cultivation ranged from 16.1 to $23.2^{\circ} \mathrm{C}$, while rainfall was $115 \mathrm{~mm}$. The soil of the experimental field showed the following characteristics: Sand $470 \mathrm{~g} \mathrm{~kg}^{-1}$ of dry soil, silt $250 \mathrm{~g} \mathrm{~kg}^{-1}$ of dry soil, clay $280 \mathrm{~g} \mathrm{~kg}^{-1}$ of dry soil, $\mathrm{pH} 7.4$ (water, 1:2.5), Electrical Conductivity (EC) $2.5 \mathrm{dS} \mathrm{m}^{-1}$, organic matter $(0.40 \%$, Lotti method), total $\mathrm{N}$ $\left(0.06 \%\right.$, Kjeldhal), available $\mathrm{P}_{2} \mathrm{O}_{5}\left(6.5 \mathrm{mg} \mathrm{kg}^{-1}\right)$ and exchangeable $\mathrm{K}_{2} \mathrm{O}\left(187.5 \mathrm{mg} \mathrm{kg}^{-1}\right)$, field capacity $26.4 \%$ of dry weight (d.w.), and wilting point $14.9 \%$ d.w.

Field experiments were performed in two adjacent fields characterized by similar weed species characteristics and consisted in a cover crop—quinoa succession. The following treatments were adapted: (1) Three winter soil managements-two agro-ecological service crops [winter vetch (Vicia sativa L., var. Macrocarpa, $\mathrm{CC}_{\mathrm{w}}$ ) and rye (Secale cereale L., var. Strategoskaia, $\left.\mathrm{CC}_{\mathrm{r}}\right)$ ] and a no cover soil $\left(\mathrm{CC}_{0}\right)$; (2) two soil tillage for preparing the quinoa sowing bed—conventional soil tillage in the $0-20 \mathrm{~cm}$ soil profile based on moldboard ploughing (CT) and no-tilled soil (ZT); (3) three herbicide rates of post-emergence 
herbicide-no application $\left(\mathrm{H}^{0}\right), 75 \%$ recommended rate $\left(\mathrm{H}^{75}\right)$, and $100 \%$ recommended rate $\left(\mathrm{H}^{100}\right)$. In the $\mathrm{H}^{0}$ treatment, hand weeding was carried out 30 days after quinoa sowing to avoid higher yield losses as observed in previous study [8], then weeds were left to grow until crop harvesting. A split-split plot design was adopted, where the winter soil management, soil tillage, and herbicide rate were the main factor, the split factor, and the split-split factor, respectively. Four replications of each treatment were adopted for a total of 72 basic plots. The size of the plots were $180 \mathrm{~m}^{2}(18 \times 10 \mathrm{~m})$ in the main plots, $90 \mathrm{~m}^{2}$ $(18 \times 5 \mathrm{~m})$ in the sub-plot size, and $30 \mathrm{~m}^{2}(6 \times 5 \mathrm{~m})$ in the sub-sub-plot size.

\subsection{Farming Practices}

In October, before agro-ecological service crops sowing, the soil was ploughed at $30 \mathrm{~cm}$ depth and the rate of $100 \mathrm{~kg} \mathrm{P}_{2} \mathrm{O}_{5} \mathrm{ha}^{-1}$ as a triple superphosphate was uniformly distributed on the soil surface. Later, the soil was tilled by disk harrowing to seedbed preparation of cover crops. Winter vetch and rye seeds were superficially distributed by hand at the rate of 100 and $180 \mathrm{~kg} \mathrm{ha}^{-1}$, respectively. The seeds were then buried at $5 \mathrm{~cm}$ depth on 10 October 2016 and 3 October 2017. The same seed rates were used in both quinoa growing seasons. In the no cover plots, seedbed preparation was performed as described above; moreover, the weeds were manually removed for the entire growing season of cover crops to keep the soil bare.

In April, two weeks before quinoa sowing, agro-ecological service crops cultivation was mechanically terminated (10 April 2017 and 18 April 2018). Then biomass of agro-ecological service crops was either (i) finely cut and placed into the soil up to $20 \mathrm{~cm}$ with moldboard plough to simulate conventional tillage practices (CT), or (ii) mowed at soil surface and arranged uniformly on the soil surface to simulate no tilled soil (ZT). In the $\mathrm{CC}_{0}$ treatment, the soil was managed by moldboard plow and disk harrowing as $\mathrm{CT}$ or left undisturbed as ZT treatments, respectively.

A tank mix of herbicides that included Metribuzin, Imazethapyr, and Pendimethalin was applied 5 days after quinoa sowing at the pre-emergence stage of the crop. These herbicides were adopted because they show low adverse effects on quinoa crop [9]. The herbicides were applied at a $100 \%$ recommendation rate $\left(\mathrm{H}^{100} \_488 \mathrm{~g} \mathrm{ha}^{-1}, 0.081 \mathrm{ha}^{-1}\right.$, and $0.661 \mathrm{ha}^{-1}$, respectively) and $75 \%$ recommendation rate $\left(\mathrm{H}^{75}-366 \mathrm{~g} \mathrm{ha}^{-1}, 0.061 \mathrm{ha}^{-1}\right.$, and $0.411 \mathrm{ha}^{-1}$, respectively). Moreover, no herbicide treatment was adopted in the experiment $\left(\mathrm{H}^{0}\right)$. A CO 2 pressurized backpack sprayer using 8003 flat-fan spray tips (Teejet spraying systems, Wheaton, IL) was used for the application of herbicides at the rate described above.

The quinoa seeds $c v$ Titikaka were sown in all plots at the density of 25 plants $\mathrm{m}^{-2}$, placing the seeds in rows with $35 \mathrm{~cm}$ of distance between rows and $10 \mathrm{~cm}$ within the rows. A ZT seed drill was used for sowing quinoa into the layer of agro-ecological service crop residues. Sowing dates were 20 April 2017 and 28 April 2018. Irrigation water by traveling irrigation gun was applied based on local practices adopted by farmers to avoid drought stress. Nitrogen fertilization was distributed twice at the rate of $112 \mathrm{~kg} \mathrm{~N} \mathrm{ha}^{-1}$ as ammonium nitrate. The first rate of nitrogen fertilization was applied on 15 April 2017 and 24 April $2018\left(56 \mathrm{~kg} \mathrm{~N} \mathrm{ha}^{-1}\right)$, while the second rate was applied on 27 May 2017 and 1 June $2018\left(56 \mathrm{~kg} \mathrm{~N} \mathrm{ha}^{-1}\right)$. Standard pest management practices of the area were adopted for pest control in quinoa. The quinoa seeds were collected manually on 15 August 2017 and on 20 August 2018 and grain yield was reported at $15.5 \%$ of moisture.

\subsection{Data Collection}

At agro-ecological service crops termination, the aboveground biomass was collected in each winter soil management treatment. A total of $1 \mathrm{~m}^{2}$ based on four sampling areas of $0.25 \mathrm{~m}^{2}$ placed four times in each plot was used to collect the aboveground biomass. Then, the collected biomass were divided for agro-ecological service crops and weeds, and dried at $70^{\circ} \mathrm{C}$. At the same time, eight soil samples per plot were collected by using a $5 \mathrm{~cm}$ diameter auger in the $0-20 \mathrm{~cm}$ layer and placed in the same container. Then, soil samples were mixed together with the aim to obtain a uniform sample to analyze for soil $\mathrm{NO}_{3}-\mathrm{N}$ content by means of colorimetric methods [10]. 
At quinoa harvesting, a soil core sampler using a $5 \mathrm{~cm}$ diameter auger was used to collect eight soil samples in the center of each plot. Samples were collected from soil depths of 0-10 and 10-20 cm, with each soil layer pooled together in plastic bags. The soil samples were preserved in laboratory incubator in dark condition and at a temperature of $4{ }^{\circ} \mathrm{C}$ to avoid undesired seed germination before their identification [11]. Weed seed identification was performed in a sub-sample of $500 \mathrm{~g}$ [12], previously treated with $1 \mathrm{~L}$ of water for $24 \mathrm{~h}$. Then, soil samples were poured through a funnel with $0.2 \mathrm{~mm}$ mesh and washed with running water at high pressure. The remaining soil, composed of seeds and debris, was placed in Petri dishes previously numbered and placed in glasshouse conditions for $24 \mathrm{~h}$. Magnifying lens was used to identify the weed seeds in the Petri dishes by counting seeds per species. Values were converted to viable seeds per square meter for each depth horizon [13].

At the same time of weed seed bank determination (quinoa harvesting), a quadrant of $1 \mathrm{~m}^{2}$ was used twice in all plots to assess the weed density and weed biomass as affected by winter soil management, soil tillage, and herbicide rate treatments. Weed density was measured by counting the number of each species per quadrat and species proportion was determined by dividing species number by total weed density number. Weed biomass was determined by cutting the weeds at soil surface after their count and pooled together into the oven until constant weight.

Quinoa injury caused by herbicides was visually estimated at 21 and 50 days after sowing (DAS) of quinoa crop. The injury was assessed from 0 (absence of plant injury) to $100 \%$ scale (full plant injury) based on leaf tissue conditions (bleaching, chlorosis and necrosis, malformation of leaves, and plant stunting). Injury determination was performed in the center of each plot in two quinoa rows $(1 \mathrm{~m})$.

\subsection{Statistical Analyses}

All data from the two-year study were subjected to the ANOVA procedure using the JMP software [14]. The agro-ecological service crops and weed biomass at agro-ecological service crops termination were analyzed using the agro-ecological service crops as a fixed factor and the year as a repeated measure. At quinoa harvesting, seed bank, weed density and biomass, and quinoa seed production were analyzed as a split-split plot experimental design where the winter soil management was the main factor, soil tillage was the split factor, the herbicide rate was the split-split factor, and the year was a repeated measure. Weed species seed density values were transformed $[\sqrt{ }(x+0.5)]$ to normalize data distribution. The data reported in the tables were back-transformed [14]. Fisher's protected least significant differences (LSD) at $p=0.05$ level of significance was used for comparing the main and interaction effects.

\section{Results}

\subsection{Cover Crop, Weed Aboveground Biomass Production, and Soil nitrate $\left(\mathrm{NO}_{3}-\mathrm{N}\right)$}

In both 2016/2017 and 2017/2018 agro-ecological service crop growing seasons, the emergence of winter vetch and rye cover crops was uniform, about 12 days after their sowing (data not shown). Both agro-ecological service crops grew regularly until their suppression in April. The agro-ecological service crop aboveground biomass was higher in winter vetch than rye (605 vs. $432 \mathrm{~g} \mathrm{~m}^{-2}$ of DM, Table 1), while weed biomass resulted lower in rye compared to winter vetch ( $38 \mathrm{vs.} 55 \mathrm{~g} \mathrm{~m}^{-2}$ of DM, Table 1). No differences were detected between 2016/2017 and 2017/2018 ( $p>0.05)$.

The soil nitrate $\left(\mathrm{NO}_{3}-\mathrm{N}\right)$ concentration measured in the $0-20 \mathrm{~cm}$ depth at agro-ecological service crop sowing and at agro-ecological service crop suppression is reported in Table 1. Generally, soil $\mathrm{NO}_{3}-\mathrm{N}$ concentration was similar among the winter soil management treatments at cover crop sowing (on average $11.6 \mathrm{mg} \mathrm{NO}_{3}-\mathrm{N} \mathrm{kg}^{-1}$ dry soil, $p>0.05$, Table 1), while, at agro-ecological service crop suppression, it was higher in winter vetch, intermediate in no cover, and the lowest in rye $\left(20.7,11.7\right.$, and $9.8 \mathrm{mg} \mathrm{NO}_{3}-\mathrm{N} \mathrm{kg}^{-1}$ dry soil, respectively). 
Table 1. The main effect of winter soil management on total cover crop aboveground biomass, weed aboveground biomass at cover crop suppression, and soil nitrate ( $\mathrm{mg} \mathrm{NO}_{3}-\mathrm{N} \mathrm{kg}^{-1}$ dry soil) on $0-20 \mathrm{~cm}$ layer (data averaged over two years, 2017-2018).

\begin{tabular}{ccc}
\hline \multicolumn{2}{c}{ Aboveground Biomass } \\
\hline \multicolumn{4}{c}{ Cover crops } & Weeds \\
$\mathrm{CC}_{\mathrm{W}}$ & $605.0^{\mathrm{a}}$ & $55.0^{\mathrm{a}}$ \\
$\mathrm{CC}_{\mathrm{r}}$ & $432.0^{\mathrm{b}}$ & $38.0^{\mathrm{b}}$ \\
& \multicolumn{2}{c}{ Soil nitrate content } \\
& $-\mathrm{mg} \mathrm{NO}_{3}-\mathrm{N} \mathrm{kg}^{-1}$ dry soil - \\
$\mathrm{CC}_{\mathrm{W}}$ & Cover crop sowing & Cover crop suppression \\
$\mathrm{CC}_{\mathrm{r}}$ & $11.6^{\mathrm{ns}}$ & $20.7^{\mathrm{a}}$ \\
$\mathrm{CC}_{0}$ & $11.6^{\mathrm{ns}}$ & $9.8^{\mathrm{c}}$ \\
& $11.8^{\mathrm{ns}}$ & $11.7^{\mathrm{b}}$ \\
\hline
\end{tabular}

$\mathrm{CC}_{0}=$ no covered soil, $\mathrm{CC}_{\mathrm{r}}=$ rye, $\mathrm{CC}_{\mathrm{w}}=$ winter vetch. Mean values on the same columns with the same letters are not significantly different $(p<0.05)$ according to Fisher's least significant differences (LSD).

\subsection{Quinoa Establishment and Yield}

The interaction among the treatment results were not significant for quinoa injury, however, herbicide rate slightly affected foliar injury of quinoa crop both at 21 and 50 days after sowing (DAS, Table 2). Generally, at 21 DAS quinoa plants showed similar level of injury in $\mathrm{H}^{75}$ and $\mathrm{H} 100$ (on average 17\%), while, as expected, no injury was observed in the H0 treatment (Table 2). At 50 days after sowing, the injury symptoms of quinoa leaves decreased greatly in all herbicide treatments showing low values, lessening to $5 \%$ in $\mathrm{H}^{75}$ and $\mathrm{H}^{100}$ and no injury in $\mathrm{H}^{0}$ (Table 2).

Table 2. Effect of herbicide rate on quinoa injury at 21 and 50 day after sowing (DAS) of quinoa (data averaged over two years, 2017 and 2018).

\begin{tabular}{ccc}
\hline Herbicide Rate & \multicolumn{2}{c}{ Crop Injury (\%) } \\
\hline & $21 \mathrm{DAS}$ & $50 \mathrm{DAS}$ \\
$\mathrm{H}^{0}$ & $0^{\mathrm{b}}$ & $0^{\mathrm{a}}$ \\
$\mathrm{H}^{75}$ & $15^{\mathrm{a}}$ & $2^{\mathrm{a}}$ \\
$\mathrm{H}^{100}$ & $18^{\mathrm{a}}$ & $4^{\mathrm{a}}$ \\
\hline
\end{tabular}

$\mathrm{H}^{0}=$ no herbicide, $\mathrm{H}^{75}=75 \%$ recommendation rate of herbicide, and $\mathrm{H}^{100}=100 \%$ recommendation rate of herbicide. Mean values on the same columns with the same letters are not significantly different $(p<0.05)$ according to the LSD.

Plant density of quinoa crop measured 21 DAS was affected by the year, winter soil management, and soil tillage as main factors, and by the interaction between winter soil management and soil tillage (Table 3). Quinoa plant density was greater in 2017 than 2018 (averagely 23.0 vs. 22.2 plants $\mathrm{m}^{-2}$, respectively), probably due to favorable weather conditions in the first quinoa growing season (data not shown). Generally, the quinoa plant density was the highest in $\mathrm{CC}_{0}-\mathrm{CT}$ and the lowest in $\mathrm{CCr}-\mathrm{ZT}$ (23.6 and 22.0 plants $\mathrm{m}^{-2}$, respectively, Table 3). It tended to be higher in $\mathrm{CC}_{0}$, intermediate in $\mathrm{CC}_{\mathrm{W}}$, and low in $\mathrm{CC}_{\mathrm{r}}$ (on average 23.3, 22.9, and 22.5 plants $\mathrm{m}^{-2}$, respectively) and on CT compared with ZT soil tillage (on average 23.3 vs. 22.5 plants $\mathrm{m}^{-2}$, respectively, Table 3).

Analysis of variance highlighted a significant interaction, winter soil management $\mathrm{x}$ soil tillage $\mathrm{x}$ herbicide rate $(p \leq 0.05)$ on seed production of quinoa. Seed yield was the greater in $\mathrm{CC}_{\mathrm{w}}-\mathrm{ZT}-\mathrm{H}^{100}$ $\left(2.61 \mathrm{t} \mathrm{ha}^{-1}\right)$ and the lowest in $\mathrm{CC}_{\mathrm{w}}-\mathrm{CT}-\mathrm{H}^{0}\left(1.24 \mathrm{tha}^{-1}\right)$ and tended to be higher in $\mathrm{CC}_{\mathrm{r}}$ followed by $\mathrm{CC}_{\mathrm{W}}$ and $\mathrm{CC}_{0}$ (averagely 2.17, 2.08, and $1.93 \mathrm{tha}^{-1}$, respectively, Table 3). Application of herbicides resulted generally in higher quinoa seed yield in $\mathrm{H}^{100}$ and $\mathrm{H}^{75}$ compared with $\mathrm{H}^{0}$ herbicide rate (on average 2.30 vs. $1.58 \mathrm{t} \mathrm{ha}^{-1}$, respectively), even if it tended to be different with the high seed yield in $\mathrm{H}^{100}$, intermediate in $\mathrm{H}^{75}$, and low in $\mathrm{H}^{0}$ under $\mathrm{ZT}$ tillage of both $\mathrm{CC}_{\mathrm{w}}$ and $\mathrm{CC}_{0}$ treatments (Table 3). Moreover, seed yield resulted to be similar in ZT and CT (averagely $2.06 \mathrm{t} \mathrm{ha}^{-1}$ ), even if in 
$\mathrm{CC}_{\mathrm{W}}$ treatments, $\mathrm{ZT}$ yielded better than $\mathrm{CT}$ treatments regardless herbicide rate (averagely $2.19 \mathrm{vs}$. $1.97 \mathrm{tha}^{-1}$, respectively).

Table 3. The interaction effect of winter soil management $\times$ soil tillage on quinoa plant density at 10 DAS and the interaction effect of winter soil management $\times$ soil tillage $\times$ herbicide rate quinoa seed yield at harvesting (data averaged over two years, 2017 and 2018).

\begin{tabular}{|c|c|c|c|c|c|}
\hline \multirow{3}{*}{ Treatmen } & & \multicolumn{4}{|c|}{ Quinoa } \\
\hline & & \multirow{2}{*}{ Plant Density (Plant $\mathrm{m}^{-2}$ ) } & \multicolumn{3}{|c|}{ Seed Yield $\left(t h^{-1}\right)$} \\
\hline & & & $\mathbf{H}^{0}$ & $\mathrm{H}^{75}$ & $\mathbf{H}^{100}$ \\
\hline \multirow{2}{*}{$\mathrm{CC}_{0}$} & $\mathrm{CT}$ & $23.6^{\mathrm{a}}$ & $1.48^{\mathrm{cC}}$ & $1.92^{\mathrm{cB}}$ & $2.27^{\mathrm{cA}}$ \\
\hline & $\mathrm{ZT}$ & $22.9^{b c}$ & $1.57^{\mathrm{bB}}$ & $2.04^{\mathrm{bA}}$ & $2.31^{\mathrm{cA}}$ \\
\hline \multirow{2}{*}{$\mathrm{CC}_{\mathrm{w}}$} & $\mathrm{CT}$ & $23.3^{\mathrm{ab}}$ & $1.44^{\mathrm{cC}}$ & $1.99 \mathrm{bB}$ & $2.47^{\mathrm{bA}}$ \\
\hline & $\mathrm{ZT}$ & $22.5^{c}$ & $1.63^{\mathrm{abB}}$ & $2.32^{\mathrm{aA}}$ & $2.61 \mathrm{aA}$ \\
\hline \multirow{2}{*}{$\mathrm{CC}_{\mathrm{r}}$} & $\mathrm{CT}$ & $23.0^{\mathrm{b}}$ & $1.66^{\mathrm{aB}}$ & $2.26^{\mathrm{aA}}$ & $2.49^{\mathrm{bA}}$ \\
\hline & $\mathrm{ZT}$ & $22.0^{\mathrm{d}}$ & $1.71^{\mathrm{aB}}$ & $2.31^{\mathrm{aA}}$ & $2.60^{\mathrm{aA}}$ \\
\hline \multicolumn{6}{|c|}{ ANOVA } \\
\hline \multicolumn{2}{|c|}{$\mathrm{Y}$} & * & \multicolumn{3}{|c|}{ ns } \\
\hline \multicolumn{2}{|c|}{ WSM } & $*$ & \multicolumn{3}{|c|}{$*$} \\
\hline \multicolumn{2}{|c|}{ ST } & $* *$ & \multicolumn{3}{|c|}{ ns } \\
\hline \multicolumn{2}{|c|}{ HR } & ns & \multicolumn{3}{|c|}{$* *$} \\
\hline \multicolumn{2}{|c|}{$\mathrm{Y}^{* W S M}$} & ns & \multicolumn{3}{|c|}{$\mathrm{ns}$} \\
\hline \multicolumn{2}{|c|}{$\mathrm{Y} * \mathrm{ST}$} & ns & \multicolumn{3}{|c|}{ ns } \\
\hline \multicolumn{2}{|c|}{$\mathrm{Y}^{*} \mathrm{HR}$} & ns & \multicolumn{3}{|c|}{ ns } \\
\hline \multicolumn{2}{|c|}{$\mathrm{Y}^{*} \mathrm{WSM}{ }^{*} \mathrm{ST}$} & ns & \multicolumn{3}{|c|}{$\mathrm{ns}$} \\
\hline \multicolumn{2}{|c|}{$\mathrm{Y}^{*} \mathrm{WSM}{ }^{*} \mathrm{HR}$} & ns & \multicolumn{3}{|c|}{ ns } \\
\hline \multicolumn{2}{|c|}{$\mathrm{Y}^{*} \mathrm{ST} \mathrm{T}^{*} \mathrm{HR}$} & ns & \multicolumn{3}{|c|}{ ns } \\
\hline \multicolumn{2}{|c|}{$\mathrm{Y}^{*} \mathrm{WSM}{ }^{*} \mathrm{ST}^{*} \mathrm{HR}$} & ns & \multicolumn{3}{|c|}{ ns } \\
\hline \multicolumn{2}{|c|}{ WSM*ST } & * & \multicolumn{3}{|c|}{$*$} \\
\hline \multicolumn{2}{|c|}{ WSM*HR } & $\mathrm{ns}$ & \multicolumn{3}{|c|}{ * } \\
\hline & & ns & & * & \\
\hline WSM & & ns & & * & \\
\hline
\end{tabular}

$\mathrm{CC}_{0}=$ no covered soil, $\mathrm{CC}_{\mathrm{r}}=$ rye, $\mathrm{CC}_{\mathrm{w}}=$ winter vetch, $\mathrm{CT}=$ conventional tillage, $\mathrm{ZT}=$ no-tillage, $\mathrm{H}^{0}=$ non herbicide, $\mathrm{H}^{75}=75 \%$ recommendation rate of herbicide, and $\mathrm{H}^{100}=100 \%$ recommendation rate of herbicide. Ns, non-significant, ${ }^{*}$ and ${ }^{* *}$, significant at the 0.05 and 0.01 level of probability, respectively; values of the same measurement followed by the same upper case letters in rows or the same lower case letters in columns are not significantly different $(p<0.05)$ according to the LSD.

\subsection{Weed Seed Bank in Quinoa Crop}

Totally, at quinoa harvesting, 13 weed species were recognized from the emerged flora (actual weeds) and seed bank (potential weeds) of the field experiment. Ten weed species were observed in both actual and potential weed flora, while only one species of the weeds was found only in soil seed bank. In both quinoa seasons, the dominant specie was Amaranthus retroflexus (on average $60.3 \%$ of the seeds in the seed bank, Table 4). Other main weed species detected were Portulaca oleracea $(7.3 \%)$, Echinochloa crus-galli (5.8\%), and Solanum nigrum (5.5\%).

Table 4. Main weed species identified in the seed bank and aboveground flora.

\begin{tabular}{ccccc}
\hline Scientific Name & Taxonomic GROUP & Presence & Life Cycle & \% Seeds in Seed Bank* \\
\hline Amaranthus retroflexus L. & Amaranthaceae & S-A & An & 60.3 \\
Ammi majus L. & Umbelliferae & S & An & 1.1 \\
Anagallis arvensis L. & Primulaceae & A & An & 1.2 \\
Chenopodium album L. & Chenopodiaceae & S-A & An & 4.1 \\
Conyza canadensis (L.) Cronq. & Asteraceae & S-A & An & 2.1 \\
\hline
\end{tabular}


Table 4. Cont.

\begin{tabular}{ccccc}
\hline Scientific Name & Taxonomic GROUP & Presence & Life Cycle & \% Seeds in Seed Bank* \\
\hline Convolvulus arvensis & Convolvulaceae & S-A & Pe & 3.3 \\
Echinochloa crus-galli (L.) Beauv. & Poaceae & S-A & $\mathrm{An}$ & 5.8 \\
Malva sylvestris L. & Malvaceae & S-A & $\mathrm{Pe}$ & 2.4 \\
Polygonum aviculare L. & Polygonaceae & $\mathrm{A}$ & $\mathrm{An}$ & 1.8 \\
Portulaca oleracea L. & Portulacaceae & S-A & $\mathrm{An}$ & 7.3 \\
Rumex crispus L. & Polygonaceae & S-A & $\mathrm{Pe}$ & 2.2 \\
Solanum nigrum L. & Solanaceae & S-A & $\mathrm{An}$ & 5.5 \\
Sorghum halepense (L.) Pers. & Poaceae & S-A & Pe & 2.9 \\
\hline
\end{tabular}

* Seed bank composition expressed as percentage of total weed seeds extracted at 0-20 cm sampling depth (data averaged over two years, 2017-2018). Pe, perennial; An, annual; B, biennial; S, seed bank; A, aboveground; $\mathrm{S}-\mathrm{A}$, present in both seed bank and aboveground.

\subsection{Weed Characteristics at Quinoa Harvesting}

Generally, the total weed seeds measured in the field experiments in the $0-20 \mathrm{~cm}$ soil depth at quinoa harvesting was influenced by winter soil management $x$ soil tillage interaction and tended to be the highest in $\mathrm{CC}_{0}-\mathrm{CT}\left(858.0\right.$ seed $\left.\mathrm{n} . \mathrm{m}^{-2}\right)$ and the lowest in $\mathrm{CC}_{\mathrm{r}}-\mathrm{ZT}\left(789.0\right.$ seed n. $\mathrm{m}^{-2}$, Table 5). Among the winter soil management, the total weed seeds were higher in $\mathrm{CC}_{0}$ than $\mathrm{CC}_{\mathrm{w}}$ and $\mathrm{CC}_{\mathrm{r}}$ treatments $\left(849.2,826.1\right.$, and 791.9 seed $n . \mathrm{m}^{-2}$, respectively), while it showed similar values between the $\mathrm{CT}$ and ZT soil tillage, except in $\mathrm{CC}_{0}$ where weed seed density was slightly higher in CT than ZT treatments (Table 5). Conversely, the vertical distribution of weed seed bank was affected by the soil tillage ( $p \leq 0.05)$. Indeed, the total weed seeds were mainly distributed in the $0-10 \mathrm{~cm}$ soil layer under both ZT and CT soil tillage, even if they tended to be higher in ZT than CT treatments (63\% vs. 55\%, respectively, Figure 1). As a consequence, the total weed seeds observed in the 10-20 cm soil layer was higher in CT compared with ZT soil tillage (45\% vs. 37\%, respectively, Figure 1). More specifically, seed density of $A$. retroflexus as the most dominant weed species followed the same trend of that described above for the vertical distribution of the total weed seeds (Figure 1).

Table 5. The interaction effects of winter soil management $\times$ soil tillage $\times$ herbicide rate on seed density of $A$. retroflexus, P. oleracea, E. crus-galli, and total weed species at quinoa harvesting in the $0-20 \mathrm{~cm}$ soil depth of no herbicide treatments $\left(\mathrm{H}^{0}\right)$ (data averaged over two years, 2017 and 2018).

\begin{tabular}{|c|c|c|c|c|c|}
\hline \multicolumn{2}{|c|}{ Treatment } & A. retroflexus & P. oleracea & E. crus-galli & Total \\
\hline & & \multicolumn{4}{|c|}{ Seed n. $\mathrm{m}^{-2}$} \\
\hline \multirow{2}{*}{$\mathrm{CC}_{0}$} & $\mathrm{CT}$ & $319.9^{a}$ & $7.9^{a}$ & $2.7^{\mathrm{a}}$ & $858.0^{a}$ \\
\hline & $\mathrm{ZT}$ & $302.3^{b}$ & $7.3^{\mathrm{a}}$ & $2.4^{\mathrm{ab}}$ & $840.5^{a b}$ \\
\hline \multirow{2}{*}{$\mathrm{CC}_{\mathrm{W}}$} & $\mathrm{CT}$ & $295.3^{b c}$ & $3.9^{b}$ & $1.8^{b}$ & $817.5^{b}$ \\
\hline & $\mathrm{ZT}$ & $302.3^{b}$ & $4.8^{\mathrm{b}}$ & $2.1^{\mathrm{ab}}$ & $834.7^{b}$ \\
\hline \multirow{2}{*}{$\mathrm{CC}_{\mathrm{r}}$} & $\mathrm{CT}$ & $288.5^{c}$ & $3.9^{b}$ & $1.8^{\mathrm{b}}$ & $794.7^{c}$ \\
\hline & $\mathrm{ZT}$ & $275.1^{\mathrm{c}}$ & $3.5^{\mathrm{b}}$ & $1.8^{\mathrm{b}}$ & $789.0^{c}$ \\
\hline \multicolumn{6}{|c|}{ ANOVA } \\
\hline \multicolumn{2}{|c|}{ Y } & ns & ns & ns & ns \\
\hline \multicolumn{2}{|c|}{ WSM } & ns & $*$ & ns & $*$ \\
\hline \multicolumn{2}{|c|}{ ST } & ns & ns & ns & ns \\
\hline \multicolumn{2}{|c|}{$\mathrm{Y}^{*} \mathrm{WSM}$} & ns & ns & ns & ns \\
\hline \multicolumn{2}{|c|}{$\mathrm{Y}^{*} \mathrm{ST}$} & ns & ns & ns & ns \\
\hline \multicolumn{2}{|c|}{$\mathrm{Y}^{*} \mathrm{WSM}{ }^{*} \mathrm{ST}$} & ns & ns & ns & ns \\
\hline \multicolumn{2}{|c|}{ WSM*ST } & $* *$ & ns & $*$ & $* *$ \\
\hline
\end{tabular}

$\mathrm{CC}_{0}=$ no covered soil, $\mathrm{CC}_{\mathrm{r}}=$ rye, $\mathrm{CC}_{\mathrm{w}}=$ winter vetch, $\mathrm{CT}=$ conventional tillage, $\mathrm{ZT}=$ no-tillage, $\mathrm{H}^{0}=$ non herbicide, $\mathrm{H}^{75}=75 \%$ recommendation rate of herbicide, and $\mathrm{H}^{100}=100 \%$ recommendation rate of herbicide. Ns, non-significant, * and **, significant at the 0.05 and 0.01 level of probability, respectively; The data are back transformed for their use in the Table. Mean values on the same columns with the same letters are not significantly different $(p<0.05)$ according to the LSD. 


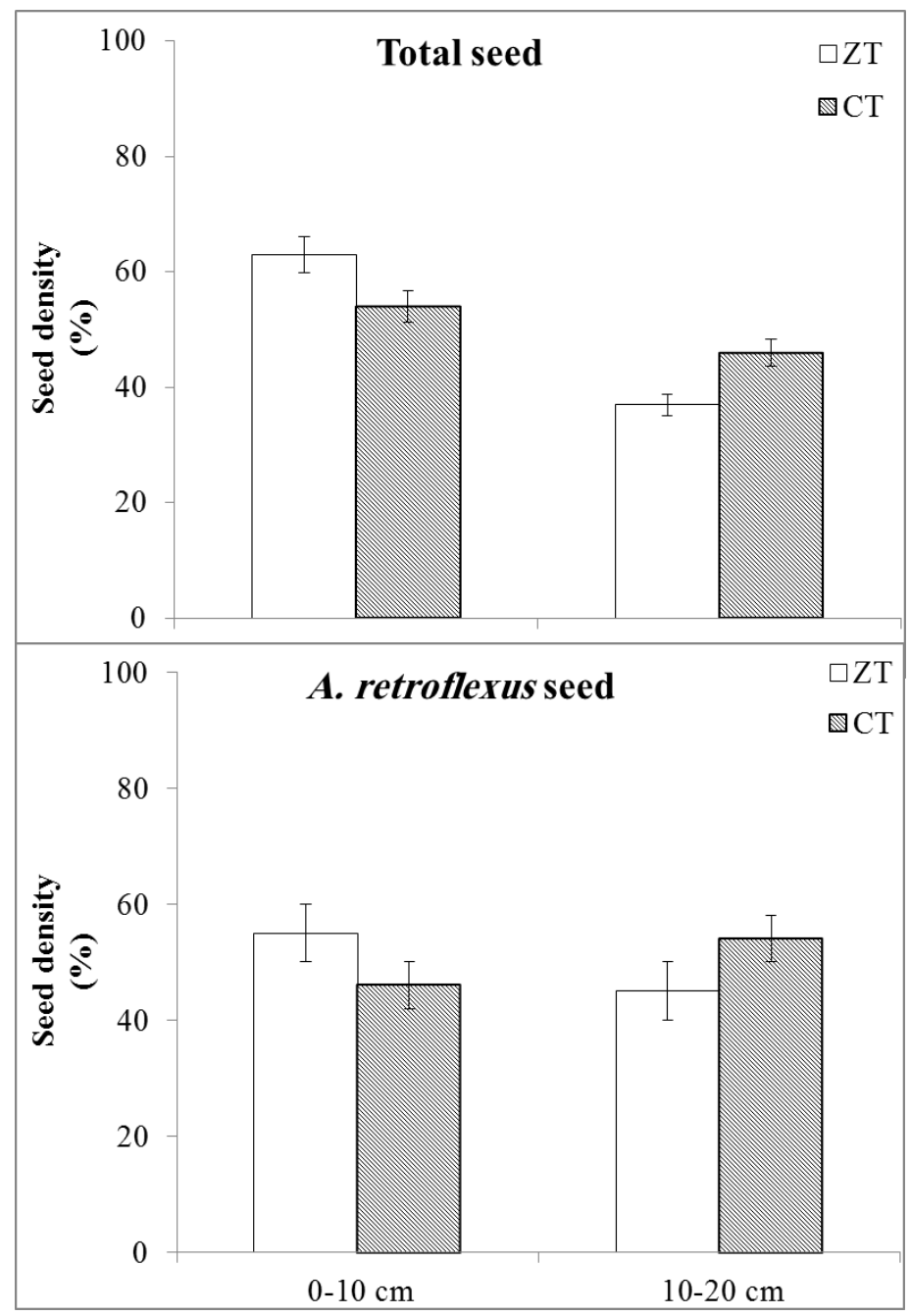

Figure 1. Vertical distribution of total weed seeds and A. retroflexus seeds observed at quinoa harvesting in $0-10$ and 10-20 cm of soil depth. CT, conventional tillage; ZT, no-tillage. Treatment means are averaged over two years, three agro-ecological service crop, soil tillage, and three herbicide treatments. Error bars represent \pm standard errors from mean (data averaged over two years, 2017-2018).

The seed density of the main dominant weed species was affected by winter soil management $x$ soil tillage interaction. Seed density of $A$. retroflexus was higher in $\mathrm{CC}_{0}-\mathrm{CT}$, followed by $\mathrm{CC}_{\mathrm{w}}$ and $\mathrm{CC}_{\mathrm{r}}$ (on average 311.1, 298.8, and 281.8 seed $\mathrm{n}^{-\mathrm{m}^{-2}}$, respectively) and varied in the similar trend among the soil tillage, excluding $\mathrm{CC}_{0}$ where the $A$. retroflexus seed density was higher in $\mathrm{CT}$ than $\mathrm{ZT}$ (Table 5 ). The P. oleracea was higher under $C_{0}$ compared with $C_{\mathrm{w}}$ and $\mathrm{CC}_{\mathrm{r}}$ treatments (on average 7.6 vs. 4.0 seed

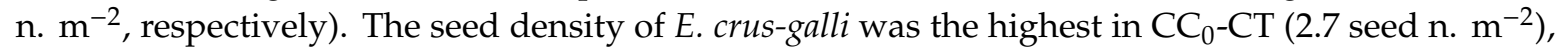
while it tended to be similar among the other treatments.

The analysis of variance showed that winter soil management, tillage management, and herbicide rate affected as main factor the density and aboveground biomass of both total weeds and A. retroflexus at quinoa harvesting, moreover there was significant interactions between them (Table 6). At quinoa harvesting, total weed density and total weed aboveground biomass followed a similar trend and, as expected, corresponded to the trend of $A$. retroflexus as predominant weed. Generally, density and biomass of total weed species were higher in $\mathrm{H}^{0}\left(42.9\right.$ plant $\mathrm{m}^{-2}$ and $352.3 \mathrm{~g} \mathrm{~m}^{-2}$, respectively), intermediate in $\mathrm{H}^{75}$ (19.7 plant $\mathrm{m}^{-2}$ and $202.8 \mathrm{~g} \mathrm{~m}^{-2}$, respectively), and low in $\mathrm{H}^{100}$ (7.1 plant $\mathrm{m}^{-2}$ and $64.0 \mathrm{~g} \mathrm{~m}^{-2}$, respectively, Table 6). 
Table 6. The interaction effects of winter soil management $\times$ soil tillage $\times$ herbicide rate on mean weed density and biomass for $A$. retroflexus and total weed species at quinoa harvesting (data averaged over two years, 2017 and 2018).

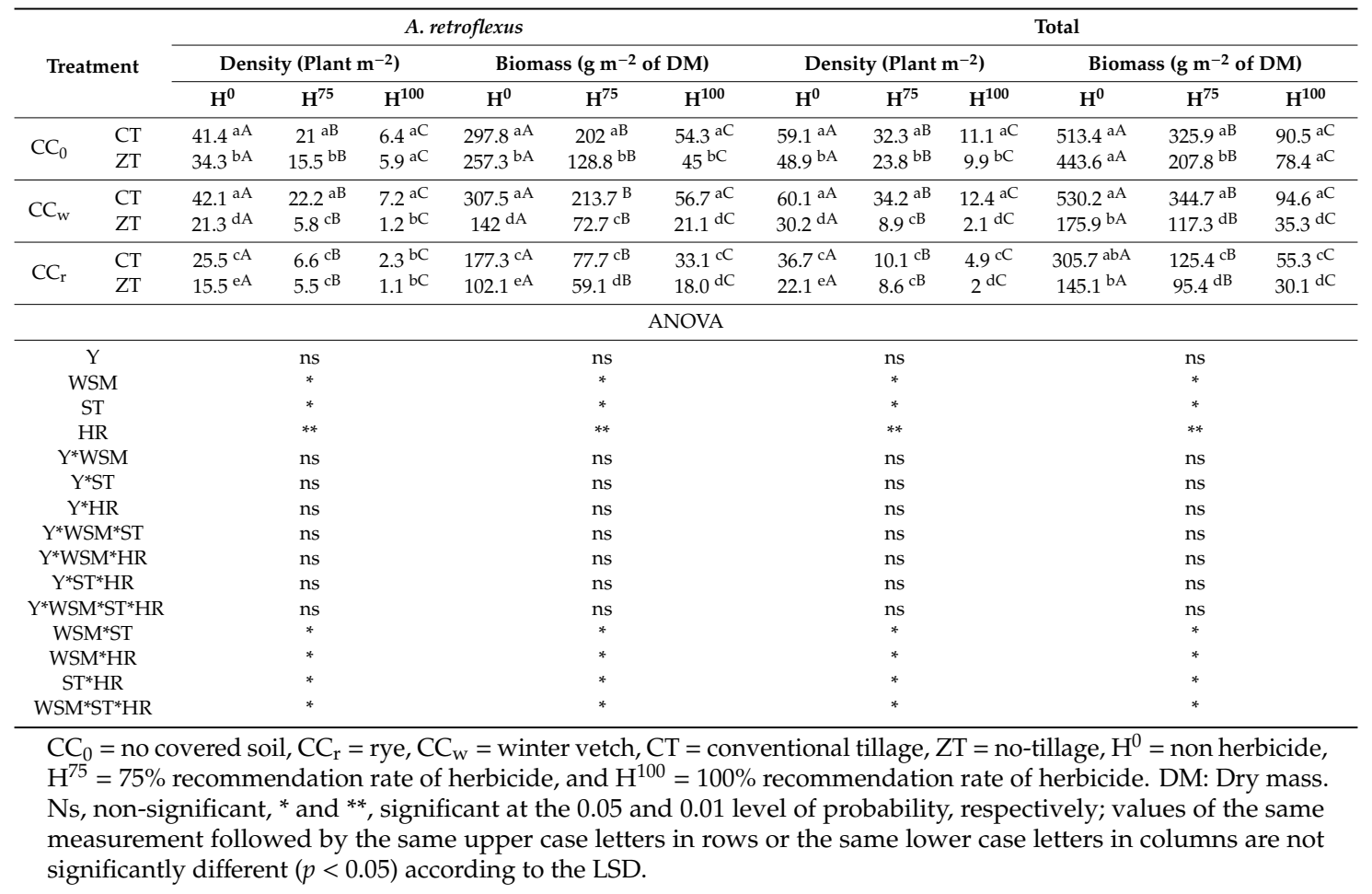

The total weed density was the highest in $\mathrm{CC}_{\mathrm{w}}-\mathrm{CT}-\mathrm{H}^{0}$ and the lowest in $\mathrm{CC}_{\mathrm{r}}-\mathrm{ZT}-\mathrm{H}^{100}$ and tended to be higher in $\mathrm{CC}_{0}$ followed by $\mathrm{CC}_{\mathrm{w}}$ and $\mathrm{CC}_{\mathrm{r}}\left(30.9,24.7\right.$ and $14.1 \mathrm{plant}^{-2}$, respectively) and under $\mathrm{CT}$ than ZT (on average 29.0 vs. 17.4 plant- $\mathrm{m}^{-2}$, respectively, Table 6).

The total weed biomass ranged from 530.2 to $30.1 \mathrm{~g} \mathrm{~m}^{-2}$ of DM in $\mathrm{CC}_{\mathrm{w}}-\mathrm{CT}-\mathrm{H}^{0}$ and $\mathrm{CC}_{\mathrm{r}}-\mathrm{ZT}-\mathrm{H}^{100}$, respectively, and follows a similar trend of that described for total weed density with high value in $\mathrm{CT}$ treatments, except in $\mathrm{CC}_{0}$ where no differences were measured in $\mathrm{CT}$ and ZT soil tillage, especially in $\mathrm{H}^{0}$ and $\mathrm{H}^{100}$ herbicide rate (Table 6). Similarly, the density and biomass data of A. retroflexus followed the same trend of total weed species measured at quinoa harvesting (Table 6).

\section{Discussion}

At agro-ecological service crop termination, rye $\left(\mathrm{CC}_{\mathrm{r}}\right)$ showed the highest weed suppression ability compared to winter vetch $\left(\mathrm{CC}_{\mathrm{W}}\right)$, even if it produced lower aboveground biomass than the legume agro-ecological service crop. Rye, as other grass agro-ecological service crops, is well known to act during its growth period as a smother crop, reducing weed establishment [15]. Moreover, rye roots could release exudates which contain allelochemical compounds that contribute to the reduction of germination and growth of weed seeds [16]. However, the adverse soil conditions that determine a reduction of seed germination of weed species due to rye cultivation could have also determined, for the same reasons, a negative impact in the main crop germination. According to this, a reduction of quinoa plant density at 10 DAS was observed. This suggests the increasing of quinoa seed density at crop sowing, when a rye is cultivated before quinoa. Furthermore, the quinoa plant establishment tended to be reduced in ZT compared with CT soil tillage, especially among the agro-ecological service crops, likely due to a residue layer of agro-ecological service crops aboveground biomass that hinder seed germination and establishment [17]. As expected, winter vetch accumulated greater nitrogen in the biomass compared to rye, confirming its ability as agro-ecological service crop to supply this nutrient throughout the decomposition process to the following crop. Accordingly, soil nitrate 
concentration after winter vetch cultivation and at quinoa sowing was higher than the other winter soil management treatments.

At quinoa harvesting, weed species were mainly detected in the actual flora compared with those of the seed bank (potential weed flora), as observed by Vasileiadis et al. [11], where 25 species emerged in the weeds and 15 species in the seed bank, but in disagreement with the findings of Zhang et al. [18], which observed 10 weed species in the actual weed flora and 18 species in the seed bank. Moreover, the number of broadleaf species was higher compared with grass species; this data is likely due to the farming history of the area that is mainly based on the wide application of chemical means, especially against grass species compared to broadleaf species. In this study, A. retroflexus was the dominant species. Cardina et al. [19] reported that in agricultural soils, weed population is generally made up by few dominant species present in elevated density, and many more weed species in reduced density. Among the weed species there were only four perennials identified in the seed bank; Convolvulus arvensis, Malva sylvestris, Rumex crispus, and Sorghum halepense, according to the observation of Singh et al. [20].

The highest number of weed seeds were found in the uppermost soil layer $(0-10 \mathrm{~cm})$ in both tillage practices, likely due to the shedding of seeds of established weeds at maturity. As expected, in the 0-10 $\mathrm{m}$ soil layer, the weed seeds number tended to be higher in $\mathrm{ZT}$ than $\mathrm{CT}$, in harmony with the statements reported by Bàrberi et al. [13] which observed that soil management practices based on reduced or no-tillage have an unevenly distributed seed bank between the two depth horizons compared to conventional tillage, showing a greater seed bank in the top soil layer. Conversely, few differences were observed in the total seed density in the whole soil profile $(0-20 \mathrm{~cm}$ layer) under the winter soil management $x$ soil tillage treatments. Similarly, Vasileiadis et al. [11] noted that, in a short period, A. retroflexus seed density was similar among soil tilled with chisel plough and moldboard plough. These results might be ascribed to the rather brief investigation period, which could account for reduced variation in the seed bank density, mainly of dominant weed species. In this sense, Cardina et al. [21] observed significant effects of tillage systems based on moldboard plow, chisel plow, and no-tillage after 35 years of experimentation on seed composition of Amaranthus spp. and E. crus-galli in a 0-10 cm soil layer.

It is well-known that the weed seed distribution vertically in the soil layers has implications in weed management; in fact, weeds germinate better if located in the upper soil layer as a consequence of proper conditions for their germination [22]. Even if weed seeds located near to the soil surface generally showed low viability in the short term referable to their high rate of germination and mortality compared to seeds situated in deeper soil layers [20]. Moreover, shallow weed seeds are subject to predators, especially insects, that leave them vulnerable [23]. Although this implies that superficial weed seeds are less interfering in seed bank management, the high germination rate occurs under minimum tillage systems due to better environmental stimuli, such as light, moisture and temperature, and a reduced presence of obstacles, therefore their quick emergence could determine problems with crop establishment and growth [22]. In this experiment, the intense weed germination observed in ZT systems rapidly led to soil cover due to weed seedlings before quinoa plants, determining intense competitive conditions for limited resources and causing the death of the quinoa seedlings. For this reason, in severe competitive environments soil tillage is necessary because it acts against weeds at the pre-emergence stage, burying weed seeds into the deeper soil where they cannot represent a problem for crop growth [24].

At the harvest time of quinoa crop, weed density and biomass measured in the bare soil were greater than winter vetch and rye straw, especially under ZT systems. Under ZT condition, the agro-ecological service crop residues are uniformly distributed in the soil surface and create an organic barrier that negatively affect environmental stimuli for seed germination of weeds, such as light, moisture, and temperature fluctuations [25]. Furthermore, the layer of biomass residues (organic dead mulch) obtained from agro-ecological service crops mowing under no-tillage (ZT) regime determined a physical obstacle, like a barrier, to emergence of weed seedlings [26,27]. Moreover, the decomposition process of agro-ecological service crop residues that begin immediately after their suppression may generate 
allelopathic substances released in the surrounding environment that affect weed seed germination and seedling survivorship [28]. It was evident when rye $\left(\mathrm{CC}_{\mathrm{r}}\right)$ was incorporated with soil, weed characteristics, in terms of density and biomass, were lower in $\mathrm{CC}_{\mathrm{r}}-\mathrm{CT}$ treatments compared with $\mathrm{CC}_{0}-\mathrm{CT}$ and $\mathrm{CC}_{\mathrm{W}}-\mathrm{CT}$. Similarly, Reddy [29] observed the rye residues showed adverse effect on weed growth. Indeed, it seems that rye residues interfere with the germination and growth of weeds, especially when CT soil tillage practice is adopted, probably due to the production of allelochemicals [16] and the reduction of available soil nitrogen [30]. On the other hand, mineralization of winter vetch residues, characterized by high nitrogen content, enhanced soil nitrogen available for the weeds. Kuo et al. [31] stated that residues of leguminous species, such as vetch, mineralize about $50 \%$ of their nitrogen in the first 30 days after their management under conventional soil tillage, likely due to favorable carbon:nitrogen (C:N) ratio compared to rye residues [32]. However, the high soil nitrogen availability due to fast mineralization process of the residues of agro-ecological service crop represents an important agronomical and environmental issue due to the complexity of synchronizing this process with the nitrogen needs and uptake of the crop [33]. This issue is particularly evident in quinoa crop, because it is characterized by a slow growth rate, especially in the stages after crop emergence. Indeed, in this study, the low suppressive activity against weeds observed in winter vetch residues incorporated into the soil was probably due to the high availability of soil nitrogen which allows weeds, particularly nitrophilous species such as A. retroflexus, to take advantage in comparison to the quinoa plants. The findings of Blackshaw et al. [34] suggest improving the agronomical practices in order to manage the mineralization process of organic materials gradually, with the aim to release nutrients, particularly nitrogen, in a more profitable way for crops compared to weeds.

The results highlight that soil tillage should be adequately combined with agro-ecological service crops to show a more effective strategy for weed control compared with bare soil. Allelochemical compounds produced by agro-ecological service crop residues and spread in the surrounding area when incorporated into the soil (CT) have stimulated a weed suppressive ability as chemical approach. However, this effect looks to be less convincing when compared with the weed suppressive ability exerted by agro-ecological service crop residues in no tillage condition (ZT) which physically prevents weed germination and growth $[35,36]$. Moreover, ploughing may bring the weed seed previously buried in the deeper soil layer to the superficial soil layer, providing more suitable environmental conditions for their germination [13], breaking their dormancy [37]. Moreover, weed seed hulls can be used by soil microbes for their nutrition, even if the C:N ratio of the hull of some weed seeds could slow down their degradation [38]. In this case, the adjunct of organic materials, characterized by low $\mathrm{C}: \mathrm{N}$ ratio, into the soil environment can affect the breaking down of the weed seed hulls stimulating the germination and, as a consequence, the reduction of weed seed bank [39]. In agreement with these statements, weed seed bank in winter vetch $\left(\mathrm{CC}_{\mathrm{W}}\right)$ in contrast to weed biomass was lower in $\mathrm{CT}$ than in ZT soil tillage (Table 5), while rye $\left(\mathrm{CC}_{\mathrm{r}}\right)$ showed an opposite trend reducing also the amount of weed seeds in the soil than the bare soil $\left(\mathrm{CC}_{0}\right.$, Table 5).

A decrease of number of weed seeds in the seed bank determined by chemical means application has been showed also by Vasileiadis et al. [11]. Buhler et al. [40] pointed out that when weeds were managed only by mechanical means such as cultivation, the seed bank was higher (about 25 times) compared to weed management strategies based on herbicides in addition to other agronomical practices. There is the general opinion that the reduction or no use of herbicides determined an increase of the weed seed bank [41]. Among the herbicide rates, $\mathrm{H}^{100}$ caused the lowest weed infestation in both years showing the great efficacy of the active compounds adopted in quinoa crop, able to reduce adverse competition of weeds under acceptable levels in a chemical weed control strategy.

As expected, quinoa yield was strongly affected by the weeds. The adaption of conventional soil tillage without application of herbicides generally resulted in a higher quinoa seed yield under rye and winter vetch cover crops than bare soil (Table 6). Although plant density of the crop was at the beginning higher in $\mathrm{CC}_{0}$ than the agro-ecological service crops $\left(\mathrm{CC}_{\mathrm{r}}\right.$ and $\left.\mathrm{CC}_{\mathrm{W}}\right)$, quinoa yield was always low in this system. This yield reduction in $\mathrm{CC}_{0}$ was associated with the high weed biomass 
as measured at quinoa harvesting. Nevertheless, the adaptation of rye and winter vetch as winter soil management do not eliminate the need of chemical means for weed control. Indeed, quinoa seed yield increased, as herbicide rate increased. This suggests that herbicide applications at the beginning of quinoa cultivation should be considered to address weed control strategies. Although full herbicide rates were required for the highest weed control and quinoa yield, cover crops, particularly managed under zero tillage conditions, improved seed yield at full herbicide rates. This suggests that an integrated approach of cover crops, zero tillage, and herbicide is required for optimum quinoa yield.

\section{Conclusions}

This study enhances the knowledge on weed species composition in quinoa crop and considers ways to improve weed management based on an integrated approach by the adoption of cover crops, zero tillage, and herbicides in order to optimize crop production. Based on the results, under ZT systems most of the weed seeds were located near the soil surface, thereby leading to a great weed density caused by an increased emergence rate of many weed species in the quinoa crop.

However, high weed seed proportion in the deeper soil layers in conventional tillage could determine the keep of the seed bank by stimulating the dormancy in weed seeds. Moreover, agro-ecological service crop residues could contribute to reduce potential and actual weeds in quinoa crops. In particular, rye was more weed suppressive than winter vetch. In the rye treatment without herbicide application, quinoa seed production was similar to that observed in no covered soil, while quinoa yield in winter vetch treatment was reduced compared with no covered soil in $\mathrm{H}^{0}$ treatment.

Overall, these findings indicate that rye and winter vetch have potential for reducing weed density in quinoa cultivation, even if the utilization only of cover crop residues as a weed management tool do not show a clear contribution for a significant effect on soil weed management. The results support that an integrated approach for weed control is important to support seed yield, in particular, the use of agro-ecological service crops in quinoa cultivation is agronomically feasible and environmentally friendly and should be supported by farmer associations.

The application of Metribuzin, Pursuit, and Pendimethalinis is suggested because it can provide both an acceptable threshold of weed density and a suitable quinoa yield seed as well.

To sum up, chemical weed control integrated with the conservation tillage such as minimum tillage along with rye residues may be a practical and sustainable option for farmers interested in the adoption of agronomical practices that supply benefits for the environment.

Author Contributions: Conceptualization, A.r.S.L. and E.R.; methodology, A.r.S.L. and E.R.; validation, A.r.S.L.; formal analysis, A.r.S.L.; investigation, A.r.S.L. and E.R.; data curation, A.r.S.L.; writing一original draft preparation, A.r.S.L., E.R., and R.M.; writing-review and editing, A.r.S.L., E.R., and R.M.; visualization, A.r.S.L., E.R., and R.M. All authors have read and agreed to the published version of the manuscript.

Funding: This research received no external funding.

Acknowledgments: The authors wish to thank Agronomy Department, Payame Noor Univeristy, Gorgan, I.R. Iran for financial support.

Conflicts of Interest: The authors declare no conflict of interest.

\section{References}

1. Bilalis, D.J.; Travlos, I.S.; Karkanis, A.; Gournaki, M.; Katsenios, G.; Hela, D.; Kakabouki, I. Evaluation of the allelopathic potential of quinoa (Chenopodium quinoa willd.). Rom. Agric. Res. 2012, 30, 359-364.

2. FAO. How to Feed the World in 2050. Insights from an Expert Meet. FAO 2009. [CrossRef]

3. Pulvento, C.; Riccardi, M.; Lavini, A.; D'Andria, R.; Iafelice, G.; Marconi, E. Field Trial Evaluation of Two Chenopodium quinoa Genotypes Grown Under Rain-Fed Conditions in a Typical Mediterranean Environment in South Italy. J. Agron. Crop Sci. 2010, 196, 407-411. [CrossRef]

4. Jacobsen, S.E.; Christiansen, J.L.; Rasmussen, J. Weed harrowing and inter-row hoeing in organic grown quinoa (Chenopodium quinoa Willd.). Outlook Agric. 2010, 39, 223-227. [CrossRef] 
5. Blackshaw, R.E.; Brandt, R.N. Nitrogen Fertilizer Rate Effects on Weed Competitiveness is Species Dependent. Weed Sci. 2008, 56, 743-747. [CrossRef]

6. Das, A.; Ghosh, P.K.; Verma, M.R.; Munda, G.C.; Ngachan, S.V.; Mandal, D. Tillage and residue mulching effect on productivity of maize (zea mays)-toria (brassica campestris) cropping system in fragile ecosystem of northeast indian himalayas. Exp. Agric. 2015, 51, 107-125. [CrossRef]

7. Osipitan, O.A.; Dille, J.A.; Assefa, Y.; Radicetti, E.; Ayeni, A.; Knezevic, S.Z. Impact of cover crop management on level of weed suppression: A meta-analysis. Crop Sci. 2019, 59, 833-842. [CrossRef]

8. Nurse, R.E.; Obeid, K.; Page, E.R. Optimal planting date, row width, and critical weed-free period for grain amaranth and quinoa grown in Ontario, Canada. Can. J. Plant Sci. 2016, 96, 360-366. [CrossRef]

9. De Barros Santos, R.L.; Spehar, C.R.; Vivaldi, L. Quinoa (Chenopodium quinoa) reaction to herbicide residue in a Brazilian Savannah soil. Pesqui. Agropecuária Bras. 2003, 38, 771-776. [CrossRef]

10. Cataldo, D.A.; Maroon, M.; Schrader, L.E.; Youngs, V.L. Rapid colorimetric determination of nitrate in plant tissue by nitration of salicylic acid. Commun. Soil Sci. Plant Anal. 1975, 6, 71-80. [CrossRef]

11. Vasileiadis, V.P.; Froud-Williams, R.J.; Eleftherohorinos, I.G. Vertical distribution, size and composition of the weed seedbank under various tillage and herbicide treatments in a sequence of industrial crops. Weed Res. 2007, 47, 222-230. [CrossRef]

12. Unger, P.W.; Miller, S.D.; Jones, O.R. Weed seeds in long-term dryland tillage and cropping system plots. Weed Res. 1999, 39, 213-223. [CrossRef]

13. Bàrberi, P.; Cozzani, A.; Macchia, M.; Bonari, E. Size and composition of the weed seedbank under different management systems for continuous maize cropping. Weed Res. 1998, 38, 319-334. [CrossRef]

14. Littell, R.C.; Milliken, G.A.; Stroup, W.W.; Wolfinger, R.D. SAS System for Mixed Models; SAS Institute: Cary, NC, USA, 1996. [CrossRef]

15. Zerner, M.C.; Gill, G.S.; Vandeleur, R.K. Effect of height on the competitive ability of wheat with oats. Agron. J. 2008, 100, 1729-1734. [CrossRef]

16. Putnam, A.R.; Defrank, J.; Barnes, J.P. Exploitation of allelopathy for weed control in annual and perennial cropping systems. J. Chem. Ecol. 1983, 9, 1001-1010. [CrossRef] [PubMed]

17. Campiglia, E.; Mancinelli, R.; Radicetti, E.; Caporali, F. Effect of cover crops and mulches on weed control and nitrogen fertilization in tomato (Lycopersicon esculentum Mill.). Crop Prot. 2010, 29, 354-363. [CrossRef]

18. Zhang, J.; Hamill, A.S.; Gardiner, I.O.; Weaver, S.E. Dependence of weed flora on the active soil seedbank. Weed Res. 1998, 38, 143-152. [CrossRef]

19. Cardina, J.; Regnier, E.; Harrison, K. Long-Term Tillage Effects on Seed Banks in Three Ohio Soils. Weed Sci. 1991, 39, 186-194. [CrossRef]

20. Singh, M.; Bhullar, M.S.; Chauhan, B.S. Influence of tillage, cover cropping, and herbicides on weeds and productivity of dry direct-seeded rice. Soil Tillage Res. 2015, 147, 39-49. [CrossRef]

21. Cardina, J.; Herms, C.P.; Doohan, D.J. Crop rotation and tillage system effects on weed seedbanks. Weed Sci. 2002, 50, 448-460. [CrossRef]

22. Chauhan, B.S.; Johnson, D.E. The role of seed ecology in improving weed management strategies in the tropics. Adv. Agron. 2010, 105, 221-262. [CrossRef]

23. Chauhan, B.S.; Migo, T.; Westerman, P.R.; Johnson, D.E. Post-dispersal predation of weed seeds in rice fields. Weed Res. 2010, 50, 553-560. [CrossRef]

24. Forcella, F.; Benech Arnold, R.L.; Sanchez, R.; Ghersa, C.M. Modeling seedling emergence. Field Crops Res. 2000, 67, 123-139. [CrossRef]

25. Shrestha, A.; Knezevic, S.Z.; Roy, R.C.; Ball-Coelho, B.R.; Swanton, C.J. Effect of tillage, cover crop and crop rotation on the composition of weed flora in a sandy soil. Weed Res. 2002, 42, 76-87. [CrossRef]

26. Radicetti, E.; Mancinelli, R.; Campiglia, E. Impact of managing cover crop residues on the floristic composition and species diversity of the weed community of pepper crop (Capsicum annuum L.). Crop Prot. 2013, 44, 109-119. [CrossRef]

27. Radicetti, E.; Mancinelli, R.; Campiglia, E. Influence of winter cover crop residue management on weeds and yield in pepper (Capsicum annuum L.) in a Mediterranean environment. Crop Prot. 2013, 52, 64-71. [CrossRef]

28. Bezuidenhout, S.R.; Reinhardt, C.F.; Whitwell, M.I. Cover crops of oats, stooling rye and three annual ryegrass cultivars influence maize and Cyperus esculentus growth. Weed Res. 2012, 52, 153-160. [CrossRef]

29. Reddy, K.N. Impact of Rye Cover Crop and Herbicides on Weeds, Yield, and Net Return in Narrow-Row Transgenic and Conventional Soybean (Glycine max) 1. Weed Technol. 2003. [CrossRef] 
30. Rosecrance, R.C.; Mccarty, G.W.; Shelton, D.R.; Teasdale, J.R. Denitrification and N mineralization from hairy vetch (Vicia villosa Roth) and rye (Secale cereale L.) cover crop monocultures and bicultures. Plant Soil 2000, 227, 283-290. [CrossRef]

31. Kuo, S.; Sainju, U.M.; Jellum, E.J. Winter Cover Cropping Influence on Nitrogen in Soil. Soil Sci. Soc. Am. J. 1997, 61, 1392-1399. [CrossRef]

32. Sainju, U.M.; Singh, B.P. Tillage, cover crop, and kill-planting date effects on corn yield and soil nitrogen. Agron. J. 2001, 93, 878-886. [CrossRef]

33. Crews, T.E.; Peoples, M.B. Legume versus fertilizer sources of nitrogen: Ecological tradeoffs and human needs. Agric. Ecosyst. Environ. 2004, 102, 279-297. [CrossRef]

34. Blackshaw, R.E.; Molnar, L.J.; Janzen, H.H. Nitrogen fertilizer timing and application method affect weed growth and competition with spring wheat. Weed Sci. 2004, 52, 614-622. [CrossRef]

35. Moonen, A.C.; Bàrberi, P. An ecological approach to study the physical and chemical effects of rye cover crop residues on Amaranthus retroflexus, Echinochloa crus-galli and maize. Ann. Appl. Biol. 2006, 148, 73-89. [CrossRef]

36. Campiglia, E.; Radicetti, E.; Mancinelli, R. Cover crops and mulches influence weed management and weed flora composition in strip-tilled tomato (Solanum lycopersicum). Weed Res. 2015, 55, 416-425. [CrossRef]

37. Ghersa, C.M.; Martínez-Ghersa, M.A. Ecological correlates of weed seed size and persistence in the soil under different tilling systems: Implications for weed management. Field Crops Res. 2000, 67, 141-148. [CrossRef]

38. Chee-Sanford, J.C.; Williams, M.M.; Davis, A.S.; Sims, G.K. Do microorganisms influence seed-bank dynamics? Weed Sci. 2006, 54, 575-587. [CrossRef]

39. Davis, A.S. Nitrogen Fertilizer and Crop Residue Effects on Seed Mortality and Germination of Eight Annual Weed Species. Weed Sci. 2007, 55, 123-128. [CrossRef]

40. Buhler, D.D.; Kohler, K.A.; Thompson, R.L. Weed Seed Bank Dynamics during a Five-Year Crop Rotation 1. Weed Technol. 2001, 15, 170-176. [CrossRef]

41. Raj, S.K.; Syriac, E.K. HErbicide mixture effect on weed seed bank in direct-seeded rice. Indian J. Weed Sci. 2018, 50, 64-68. [CrossRef]

(C) 2020 by the authors. Licensee MDPI, Basel, Switzerland. This article is an open access article distributed under the terms and conditions of the Creative Commons Attribution (CC BY) license (http://creativecommons.org/licenses/by/4.0/). 